\title{
Research on the credit risk of small and micro enterprises under "The Belt and Road Initiative"
}

\author{
Zhanyu Liu ${ }^{1,2}$, Xialing Sun ${ }^{1, a}$ \\ ${ }^{I}$ Research Center for Energy Economy, Henan Polytechnic University, 454000 Jiaozuo, China \\ ${ }^{2}$ Taihang Development Research Institute, Henan Polytechnic University, 454000 Jiaozuo, China
}

\begin{abstract}
Under the "The Belt and Road Initiative", small and micro enterprises have new opportunities and new challenges. At present, the biggest problem facing the development of small and micro enterprises is the financing problem, and it is imminent to solve the financing problem. Based on the actual situation of small and micro enterprises, this paper designs a credit risk evaluation index system for small and micro enterprises through literature analysis and questionnaire, makes an empirical analysis on the $\mathrm{H}$ e-commerce enterprises in Henan province. On this basis, the credit risk control strategy of small and micro enterprises is put forward at the end of the article.
\end{abstract}

\section{Introduction}

The concept of "The Belt and Road Initiative" is a national decision promoted by China at the initiative level with a view to promoting the common development and prosperity of China and other countries along the line. It is a new platform for international cooperation. In 2016, the transaction volume of China's cross-border e-commerce market reached 6.7 trillion yuan, an increase of $24 \%$ over the previous year. The export cross-border electricity supplier market trading scale of 5 trillion and 500 billion yuan, an increase of $22.2 \%$, the import cross-border electricity supplier market trading scale of 120 million yuan, an increase of $33.3 \%$. The proposal of the "The Belt and Road Initiative" strategic concept has provided an opportunity platform for complementary cooperation and open development for the countries and regions along the line.

This is the first time that China has proposed a China-led intercontinental development cooperation framework in the past 200 years and will completely shake off its original development cooperation. Henan is a key node in the construction of the silk road economic belt, which will bring huge business opportunities and challenges to the development of small and micro enterprises. Based on the strategy of "The Belt and Road Initiative" and under the influence of the "Mass Entrepreneurship and Innovation" policy, small and micro enterprises have become an important part of the national economy [1]. The biggest problem facing the development of small and micro enterprises is the financial problem, while bank loans are often the main financing means for small and micro enterprises [2]. However, small and micro enterprises tend to receive lower credit support than large-scale enterprises and thus are forced to accept credit services with higher interest rates. As a result, the development of many small and micro-enterprises lacks lasting power with low survival rates [3]. Therefore, this article tries to analyze the actual conditions of the development of small and micro enterprises, builds the bank credit risk evaluation index system for small and micro enterprises, and empirically analyzes the small and micro enterprises $\mathrm{H}$ electricity companies in Henan Province. Finally, reasonable countermeasures and Suggestions are put forward.

\section{Design of credit risk evaluation index system for small and micro enterprises}

Establishing an accurate and reasonable risk assessment system for small and micro enterprises is imminent. It will be an important support for the development of small and micro enterprises.

\subsection{Selection of credit risk assessment indicators for small and micro enterprises}

In connection with the evaluation index system of credit risk of many domestic banks, the evaluation indexes of credit risk of small and micro enterprises are sorted out and the main indicators are divided. Among them, the credit risk assessment indicators for small and micro enterprises loans can be divided into three levels: macro indicators, mid-term indicators and mainly industrial development, while micro-indicators can be divided into four categories: corporate solvency, corporate operating capacity, corporate profitability and other indicators. In order to ensure the reliability of index selection and calculation convenience, we conducted research and consultation on 26 multi-year credit workers, including

* Corresponding author: ${ }^{\text {a } 941110879 @ q q . c o m}$ 
14 on-site visits and 12 on-line research. After communicating with professionals in different companies and different ranks, we fully consider the many important factors that affect the credit risk of loans to small and micro enterprises. After screening, 19 indicators are used as evaluation factors. The evaluation index system of credit risk of small and micro enterprises is a hierarchical structure composed of 19 factors.

It is necessary to introduce the specific connotation of each factor during the investigation so as to facilitate the correct cognition. And on this basis to make a professional rating and specific assignment. With reference to relevant research, the five levels of Likert scale were used to divide the evaluation objects into five levels and correspond to the different connotations of different indicators respectively. In order to facilitate the data statistics and model calculation, the value of the assignment is ten points. The lower level is $0-2$, the general level is $2-4$, the preferably grade is $4-6$, the good grade is 6-8, and the excellent grade is 8-10.

Table 1. Credit risk assessment system for small and micro enterprises

\begin{tabular}{|c|c|c|}
\hline Evaluation index & Criterion layer & Indicator layer \\
\hline Macro indicator (A1) & $\begin{array}{l}\text { Macroeconomic } \\
\text { conditions (B1) }\end{array}$ & $\begin{array}{c}\text { Business and investment environment (C1) } \\
\text { Macroeconomic Policy (C2) } \\
\text { Economic Prosperity (C3) }\end{array}$ \\
\hline $\begin{array}{l}\text { Mid-scale indicator } \\
\text { (A2) }\end{array}$ & $\begin{array}{l}\text { Industrial development } \\
\text { (B2) }\end{array}$ & $\begin{array}{c}\text { Industry Product Replaceability (C4) } \\
\text { Industry Life Cycle (C5) } \\
\text { Industry Technology Level (C6) }\end{array}$ \\
\hline \multirow{5}{*}{ Micro-indicators (A3) } & Corporate solvency (B3) & $\begin{array}{c}\text { Working capital ratio (C7) } \\
\text { Asset-liability ratio (C8) } \\
\text { Current Ratio (C9) } \\
\text { Inventory turnover (C10) }\end{array}$ \\
\hline & $\begin{array}{l}\text { Corporate operating } \\
\text { capacity (B4) }\end{array}$ & $\begin{array}{c}\text { Total Asset Turnover }(\mathrm{C} 11) \\
\text { Accounts receivable turnover (C12) }\end{array}$ \\
\hline & & Gross profit margin (C13) \\
\hline & $\begin{array}{l}\text { Corporate profitability } \\
\text { (B5) }\end{array}$ & $\begin{array}{c}\text { Return on net assets }(\mathrm{C} 14) \\
\text { Main business profit margin }(\mathrm{C} 15)\end{array}$ \\
\hline & Other indicators (B6) & $\begin{array}{l}\text { Local government support (C16) } \\
\text { Managerial ability }(\mathrm{C} 17) \\
\text { Quality of staff }(\mathrm{C} 18) \\
\text { Bad record (C19) }\end{array}$ \\
\hline
\end{tabular}

\subsection{Determination of weight of evaluation index system}

Based on a reasonable weight of the credit risk of small and micro enterprises loans, the evaluation results will be more ideal. Analytic Hierarchy Process (AHP) can combine qualitative analysis with quantitative analysis. It is also more applicable to the index system established in this paper $[4,5]$. Therefore, this paper attempts to use AHP to determine the weight of loan credit risk evaluation index of small and micro enterprises.

1) Establishing discriminant matrix $\mathrm{A}$

$$
\left(\begin{array}{ccccrr}
1 & 1 / 2 & 1 / 6 & 1 / 4 & 1 / 5 & 1 / 3 \\
2 & 1 & 1 / 4 & 1 & 1 / 3 & 1 / 2 \\
6 & 4 & 1 & 4 & 2 & 3 \\
4 & 1 & 1 / 4 & 1 & 1 / 2 & 1 / 2 \\
5 & 3 & 1 / 2 & 2 & 1 & 3 \\
3 & 2 & 1 / 3 & 2 & 1 / 3 & 1
\end{array}\right)
$$

2) Normalized by column to get matrix B

$\left(\begin{array}{llllll}0.048 & 0.043 & 0.067 & 0.024 & 0.046 & 0.040 \\ 0.095 & 0.087 & 0.100 & 0.098 & 0.076 & 0.060 \\ 0.286 & 0.348 & 0.400 & 0.390 & 0.458 & 0.360 \\ 0.190 & 0.087 & 0.100 & 0.098 & 0.115 & 0.060 \\ 0.238 & 0.261 & 0.200 & 0.195 & 0.229 & 0.360 \\ 0.143 & 0.174 & 0.133 & 0.195 & 0.076 & 0.120\end{array}\right)$

3) Summing the rows of the matrix to obtain the matrix V

$\left(\begin{array}{l}0.268 \\ 0.516 \\ 2.242 \\ 0.649 \\ 1.483 \\ 0.842\end{array}\right)$

4) Normalized by column to get matrix W

0.086

0.374

0.108

0.247

0.140

5) Consistency check

$C I=\frac{\lambda_{\max }-n}{n-1}, \lambda_{\max }=\frac{1}{n} \sum_{i}\left(\frac{(A W)_{i}}{\omega_{i}}\right)$ 


$$
\begin{aligned}
& A W=\left(\begin{array}{c}
0.2734 \\
0.5298 \\
2.3340 \\
0.6610 \\
1.5530 \\
0.8700
\end{array}\right), \lambda_{\max }=6.1831 \\
& C I=\frac{\lambda_{\max }-n}{n-1}=\frac{6.1831-6}{5}=0.0366 \\
& C R=\frac{C I}{R I}=\frac{0.0366}{1.26}=0.0291<0.10
\end{aligned}
$$

Therefore, the matrix is consistent, indicating that the weight vector is reliable. By investigating the questionnaire, we set up the judgment matrix, the normalization process and the consistency check procedure, and obtain the weight of the criterion layer in order of $0.045,0.086,0.374,0.108,0.247,0.140$ respectively. In the same way, we obtain the weight of

\begin{tabular}{|c|c|c|c|c|}
\hline Criterion layer & Weights & Indicator layer & Weights & Total weight \\
\hline \multirow{4}{*}{$\begin{array}{l}\text { Macroeconomic } \\
\text { conditions (B1) }\end{array}$} & \multirow{3}{*}{0.045} & Business and investment environment (C1) & 0.401 & 0.018 \\
\hline & & Macroeconomic Policy $(\mathrm{C} 2)$ & 0.322 & 0.014 \\
\hline & & Economic Prosperity (C3) & 0.277 & 0.012 \\
\hline & \multirow{4}{*}{0.086} & Industry Product Replaceability (C4) & 0.453 & 0.039 \\
\hline \multirow{3}{*}{$\begin{array}{c}\text { Industrial } \\
\text { development (B2) }\end{array}$} & & Industry Life Cycle (C5) & 0.274 & 0.024 \\
\hline & & Industry Technology Level (C6) & 0.273 & 0.023 \\
\hline & & Working capital ratio (C7) & 0.312 & 0.117 \\
\hline \multirow{2}{*}{$\begin{array}{l}\text { Corporate solvency } \\
\text { (B3) }\end{array}$} & \multirow[b]{2}{*}{0.374} & Asset-liability ratio (C8) & 0.521 & 0.195 \\
\hline & & Current Ratio (C9) & 0.167 & 0.062 \\
\hline \multirow{4}{*}{$\begin{array}{c}\text { Corporate operating } \\
\text { capacity (B4) }\end{array}$} & \multirow{4}{*}{0.108} & Inventory turnover $(\mathrm{C} 10)$ & 0.411 & 0.044 \\
\hline & & Total Asset Turnover (C11) & 0.236 & 0.025 \\
\hline & & Accounts receivable turnover $(\mathrm{C} 12)$ & 0.353 & 0.038 \\
\hline & & Gross profit margin $(\mathrm{C} 13)$ & 0.517 & 0.128 \\
\hline \multirow{3}{*}{$\begin{array}{c}\text { Corporate } \\
\text { profitability (B5) }\end{array}$} & \multirow{3}{*}{0.247} & Return on net assets (C14) & 0.139 & 0.034 \\
\hline & & Main business profit margin $(\mathrm{C} 15)$ & 0.344 & 0.085 \\
\hline & & Local government support (C16) & 0.276 & 0.039 \\
\hline \multirow{3}{*}{$\begin{array}{l}\text { Other indicators } \\
\text { (B6) }\end{array}$} & \multirow{3}{*}{0.140} & Managerial ability (C17) & 0.245 & 0.034 \\
\hline & & Quality of staff (C18) & 0.102 & 0.014 \\
\hline & & Bad record (C19) & 0.377 & 0.053 \\
\hline
\end{tabular}
indicator layer, as shown in Table 2.

Table 2. Index weight of credit risk assessment of small and micro enterprises

\section{Empirical analysis based on $h$ e-commerce enterprise}

We choose $\mathrm{H}$ e-commerce enterprise in Henan Province as an empirical research object and conduct credit risk rating description with five grades. We conducted a survey by designing a questionnaire [6]. There are 20 valid questionnaires, which are from 6 H-related practitioners, 10 bank credit officers, and 4 university-related professional teachers. According to the research results, the paper establishes the fuzzy evaluation matrix and makes a comprehensive evaluation on the six criteria indicators of the macroeconomic conditions, industrial development, corporate solvency, corporate operating capability, corporate profitability and other indicators. Taking macroeconomic conditions as an example, we can establish discriminant matrix as $R_{1}$.

$$
\begin{aligned}
& R_{1}=\left(\begin{array}{lllll}
10 & 6 & 3 & 1 & 0 \\
12 & 7 & 1 & 0 & 0 \\
11 & 5 & 3 & 1 & 0
\end{array}\right) \\
& B_{1}=A_{1} \cdot R_{1} \\
& =\left(\begin{array}{lll}
0.018 & 0.014 & 0.012
\end{array}\right)\left(\begin{array}{ccccc}
10 & 6 & 3 & 1 & 0 \\
12 & 7 & 1 & 0 & 0 \\
11 & 5 & 3 & 1 & 0
\end{array}\right) \\
& =\left(\begin{array}{lllll}
0.4800 & 0.2660 & 0.1040 & 0.0300 & 0.0000
\end{array}\right)
\end{aligned}
$$

Normalized by column to get matrix $B_{1}=\left(\begin{array}{lllll}0.5455 & 0.3023 & 0.1182 & 0.0341 & 0.0000\end{array}\right)$

According to the data processing, $54.55 \%$ of the experts think that the current economic environment of $\mathrm{H}$ is excellent, $30.23 \%$ of experts think H's current economic environment is good, $11.82 \%$ of experts think $\mathrm{H}$ 's current economic environment is preferably, $3.41 \%$ of experts believe that the current economic environment of $\mathrm{H}$ is general, no experts believe that current economic environment is poor. In general, the current economic conditions of $\mathrm{H}$ e-commerce enterprise are the best indicators in the guideline layer. Using the same method can calculate the weight of other indicators.

In accordance with the credit risk evaluation standard interval, and for the sake of comparative analysis, we take the upper limit of all the valuation intervals as the final evaluation criteria for the bank credit risk evaluation of small and micro enterprises, 10 points for the full score, that is, five Credit levels were taken as $2,4,6,8,10$ points [7-9]. The formula of credit risk calculation for $\mathrm{H}$ e-commerce enterprise is $V=\sum_{i=1}^{n} v_{i} b_{i}$. Therefore, in the case of a perfect score of 10, the credit risk evaluation score of $\mathrm{H}$ e-commerce enterprise is 7.7288. According to the Bank's credit risk evaluation criteria for small and micro enterprises loans, the final 
score of the enterprise fell in the range of 6-8, that is, the enterprise has a good credit rating, second only to excellent. On the whole, the credit level of $\mathrm{H}$ e-commerce enterprises is relatively ideal, the investment risk is not very big, and the debt paying ability of the enterprises is strong. The bank can consider making loans to $\mathrm{H}$ e-commerce enterprise.

We returned the above evaluation results to the experts under investigation and received the following feedback $[10,11]$. The credit risk evaluation results of loans to $\mathrm{H}$ e-commerce enterprise basically accord with the actual situation, which can reasonably and fairly evaluate the loan risk situation.

\section{Credit risk control strategy for small and micro enterprises}

\subsection{Increase government's dominance and help}

In order to make small and micro enterprises develop as soon as possible, relying solely on the market mechanism is not feasible, the government must give legal support to the financial policy support of enterprises. According to the policies and measures promulgated by the state, formulate policies to encourage small and medium-sized enterprises to get preferential support from the state. Gradually establish a pluralistic, multi-level and all-round incentive policy. The service system should be guided by the government and run by the association of private enterprises. A series of outstanding policies and measures for small and micro businesses should be designated, including organizing small and micro businesses to join Chambers of commerce at all levels, strengthening service, and accelerating the healthy development of small and micro enterprises.

\subsection{Establish and improve the market supervision system}

Cross-border e-commerce transactions are characterized by globalization, electronicization and virtualization. Cross-border e-commerce faces the challenges and threats of fake fraud and consumer rights protection. Therefore, it is necessary and urgent to establish and perfect the market supervision system. Accelerating the development of cross-border e-commerce regulatory information systems and establishing cross-departmental information sharing and coordination mechanisms are important. It is also necessary to improve the integrity system and create a fair market environment. Relevant departments should improve the integrity system, crack down on counterfeit and shoddy goods and practices that violate intellectual property rights in cross-border e-commerce. Based on the development of cross-border e-commerce to enhance the ability to detect problems and the ability to deal with emergencies.

\subsection{Strengthen the management of loan process}

Since the ratio of non-performing loans of small and micro enterprises is higher than that of other types of enterprises, banks, in order to ensure a stable capital structure, set up the overall objective of credit risk for small and micro enterprises. The default rate of loans for small and micro enterprises is controlled within 1.5\%, the guaranteed loan recovery rate exceeds $96 \%$, and the capital's profit rate exceeds $5 \%$. It is necessary to strictly assess the impact of major changes in small and micro enterprises on the development prospects of credit customers, strictly control access to third-party mortgage loans, and prevent borrowers from over-capitalizing or over-financing, which in turn leads to impaired bank revenue. Finally, it is necessary to improve the evaluation mechanism of post-loan managers, strengthen their ability to collect and analyze information, improve their information screening capabilities and comprehensive service capabilities, and take effective measures to control loan credit risks.

\section{Conclusions}

It provides development opportunities for small and micro enterprises through "The Belt and Road Initiative". One of the important problems faced by small and micro enterprises is capital. It is of great practical significance to study the credit risk of small and micro enterprises under "The Belt and Road Initiative". Taking H enterprise of Henan Province as an example, this paper makes a study and obtains that it can grant loans under the relevant evaluation system. In the future, different development strategies should be proposed for the development of small and micro enterprises with different attributes.

\section{Acknowledgment}

This work is supported by Pre-research on the National Social Science Fund of HPU (GSKY2017-28), Youth Backbone Teacher Funding Program of HPU (2017XQG-13) and Government Decision Study of Jiaozuo (JZ2018ZB06).

\section{Reference}

1. A. Blanco, R. Pino-Mejias, J. Lara, S. Rayo, Expert Systems with Applications 40(1), 356 (2013)

2. T. Kalniuk, Visnyk NAU 2(22), 14-16 (2015)

3. W. Shang, Y. Gong, Z. Wang, M.J. Stewardson, Journal of Environmental Management 210, 162-170 (2018)

4. Y. Nikaido, J. Pais, M. Sarma, Review of Development Finance 5(1), 43-52 (2015)

5. R.N. Lussier, S. Pfeifer, Journal of Small Business Management 39(3), 228-229 (2010)

6. A. Caldarelli, C. Fiondella, M. Maffei, C. Zagaria, Management Accounting Research 32, 1-15 (2016)

7. S. Schomers, B. Matzdorf, Ecosystem Services 6, 16-30 (2013) 
8. I.N. Aleksandrov, M.Y. Fedorova, Scientific Journal of KubSAU 10, 1-11 (2017)

9. I. Polyakova, E. Chibisova, Economics and Entrepreneurship 5(70), 579-582 (2016)

10. M.A. Bahauovna, International Journal of Applied Engineering Research 10(23), 43446-43449 (2015)

11. T. Meshcheriakova, Economics and Entrepreneurship 10(1), 520-526 (2017) 